\title{
Sejarah Pemikiran Ekonomi Islam dari Masa Rasulullah sampai Masa Kontemporer
}

Oleh :

\author{
Sri Maghfirah (90100118029) \\ Ekonomi Islam A (2018 \\ srimaghfirah@icloud.com
}

\section{PENDAHULUAN}

Dari literatur-literatur yang telah diteliti oleh para pemikir ekonomi Islam, kita hanya mendapatkan sedikit buku yang secara khusus mengulas tentang ekonomi Islam. Salah satu ulama kontemporer yang memberikan idenya tentang ekonomi Islam adalah Muhammad al-Ghazali (al-Islam wa al-Auda' al-Iqtis adiyah, Islam dan Kedudukan Ekonomi) dan Sayyid Qutb (al-'Adalah alIjtima 'iyyah fi al-Islam, Keadilan Sosial dalam Islam). Dari permasalahan tersebut maka ruang lingkup studi tentang ekonomi Islam sangat terbatas.

Dalam artikel ini akan dikaji tentang sejarah pemikiran ekonomi Islam pada masa Rasulullah sampai pada masa kontemporer yang menjadi titik awal mula tonggak ekonomi Islam ditegakkan. Dengan tujuan menjadikan landasan-landasan ekonomi Islam yang telah muncul seiring dengan kebijakan Rasulullah SAW terkait dengan ekonomi masyarakat Madinah saat itu.

\section{Masa Rasulullah SAW (570 M)}

Rasulullah adalah seorang pedagang profesional dan selalu menjunjung tinggi kejujuran maka dari itu beliau mendapatkan julukan al-Amin (yang terpercaya). Ketika masyarakat Muslim telah berhijrah ke Madinah, Rasulullah pun memiliki peran sebagai pengawas pasar (al-Muhtasin) yang bertugas mengawasi mekanisme pasar agar tetap berjalan sesuai dengan ajaran agama Islam. Pada saat itu, mekanisme pasar sangat dihargai manakala beliau menolak untuk menetapkan kebijakan harga yang saat itu mengalami kenaikan karena kuatnya penawaran dan permintaan pasar. ${ }^{1}$

\footnotetext{
${ }^{1}$ DJAWAHIR HEJAZZIEY, 'Mekanisme Pasar Dalam Perspektif Ekonomi Islam', Alqalam, 28.3 (2019), 535 <https://doi.org/10.32678/alqalam.v28i3.889>.
} 


\section{Khalifah (632 M)}

Pada saat Rasulullah wafat, Abu Bakar melanjutkan tugas perekonomian Islam dengan memfokuskan pada keakuratan pembayaran zakat. Dengan sikap tegas memerangi golongan yang menolak membayar zakat. Masa Umar bin Khattab kegiatan ekonomi Islam semakin maju dan luas dimana masa pengelolaan Baitul Mal dan pajak pengelolaan tanah yang disita dari negara ditaklukkan. Pada masa Utsman, beliau mengambil kebijakan menolak upah dari kantornya karena ingin meringankan beban pemerintah. Selanjutnya masa Ali bin Abi thalib mempunyai prinsip bahwa pemerataan distribusi uang masyarakat harus sesuai dengan kapasitasnya. $^{2}$

\section{Dinasti (661 M)}

Pada masa al-Gazali dalam alur sejarah pemikiran ekonomi Islam beliau masuk kepada fase II, yang dilatarbelakngi merajalelanya korupsi dan dekadensi moral. Pemikiran ekonomi al-Gazali didasari oleh pendekatan tasawuf karena pada masa hidupnya dikelilingi orang-orang yang berkuasa dan sulit menerima pendekatan fiqih dan filosofis dalam mempercayai Yaum al-Hisab. ${ }^{3}$

\section{Kontemporer (1930 M-Sekarang)}

Mannan mengkritik mengenai neoklasik mengenai distribusi, pandangannya mendasar pada kerangka neoklasik. Sekalipun menyebutkan pentingnya kebutuhan akan suatu teori distribusi persona dan teori kepemilikan sumber daya dan penetapan harga, ia tidak memberikan sumbangan orisinal disini. Walau penekanannya secara konstan kepada pentingnya distribusi layak dipuji, kekurangan analisisnya akan hal-hal tersebut menjadikan kekurangan tersebut perlu diperbaiki. $^{4}$

\footnotetext{
${ }^{2}$ Gubernur Kufah, 'Analisis Sejarah Pemikiran Ekonomi Islam Masa Klasik', 8.2, 189-210.

${ }^{3}$ Sirajuddin, 'Sirajuddin, "Konsep Pemikiran Ekonomi Al-Ghazali” Al-Qisthu: Jurnal Laa Maisyir, Vol. 3, No.1 (Juni 2016)'.

${ }^{4}$ Ali Hamzah and Mhd. Rasidin, 'Pemikiran Ekonomi Islam Kontemporer: Kajian Teoritis Muhammad Abdul Mannan Tentang Distribusi', Al-Qisthu: Jurnal Kajian IImu-IImu Hukum, 18.1 (2020), 22-28 <https://doi.org/10.32694/010860>.
} 


\section{DAFTAR PUSTAKA}

Ali Hamzah and Mhd. Rasidin, 'Pemikiran Ekonomi Islam Kontemporer: Kajian Teoritis Muhammad Abdul Mannan Tentang Distribusi', Al-Qisthu: Jurnal Kajian Ilmu-Ilmu Hukum, $18.1 \quad$ (2020), 22-28 <https://doi.org/10.32694/010860>.

DJAWAHIR HEJAZZIEY, 'Mekanisme Pasar Dalam Perspektif Ekonomi Islam', Alqalam, 28.3 (2019), 535 <https://doi.org/10.32678/alqalam.v28i3.889>.

Gubernur Kufah, 'Analisis Sejarah Pemikiran Ekonomi Islam Masa Klasik', 8.2, $189-210$.

Sirajuddin, "Sirajuddin, "Konsep Pemikiran Ekonomi Al-Ghazali" Al-Qisthu: Jurnal Laa Maisyir, Vol. 3, No.1 (Juni 2016)'.

Ali Hamzah and Mhd. Rasidin, 'Pemikiran Ekonomi Islam Kontemporer: Kajian Teoritis Muhammad Abdul Mannan Tentang Distribusi’, Al-Qisthu: Jurnal Kajian Ilmu-Ilmu Hukum, $18.1 \quad$ (2020), 22-28 <https://doi.org/10.32694/010860>. 